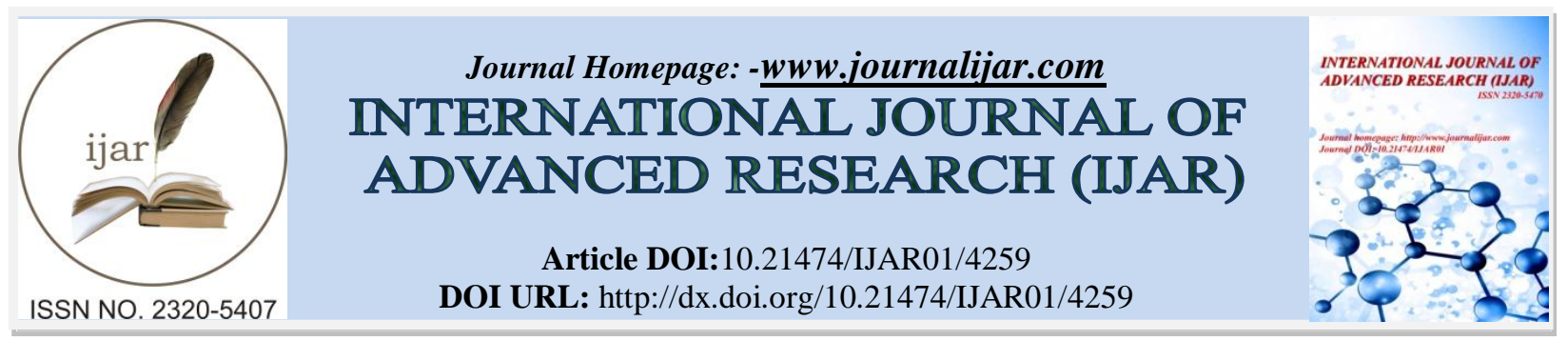

RESEARCH ARTICLE

\title{
GENETIC VARIABILITY CHARACTERIZATION OF SOME EX SITU CONSERVED FINGER MILLET (ELEUSINE CORACANA (L.) GAERTN. SUBSP. CORACANA) GERMPLASM ACCESSIONS IN SRI LANKAUSING QUALITATIVE MORPHOLOGICAL MARKERS.
}

"P. N. Dasanayaka ${ }^{1}$ and D. V. S. Kaluthanthri ${ }^{1}$.

Department of Botany, Faculty of Applied sciences, University of Sri Jayewardenepura, Nugegoda, Sri Lanka.

\section{Manuscript Info}

Manuscript History

Received: 27 March 2017

Final Accepted: 30 April 2017

Published: May 2017

Key words:-

Finger millet, Germplasm,

Characterization, Qualitative traits.

\section{Abstract}

Finger millet (Eleusinecoracana) [order Poales, family Poaceae, sub family Chloridoideae] ranks fourth in importance among milletsin the world. This crop is grown in the arid and semiarid regions of the world. E. coracanahas a greater nutritional value. This study was performed on 42 germplasm accessions of finger millet conserved at the Plant Genetic Resource Center (PGRC), Gannoruwa, Sri Lanka. These germplasm accessions comprised of 27 Sri Lankan accessions, 11 Indian accessions, 2 Zimbabian accessions and 2 recommended varieties of Sri Lanka. Qualitative traits taken into consideration were Pigmentation, Growth habit, Ear shape, Ear size, Finger branching, Discontinuity of spikelet, Lodging susceptibility, Spikelet shattering, Grains covering by glumes, Grain colour, Grain shape and Grain surface. Out of them, Pigmentation and Finger branching were monomorphic for the studied accessions while rest of ten traits were polymorphic. Characters were scored following International Plant Genetic Resource Institute (IPGRI) descriptors developed for finger millet. The majority of individual plants was found to possess erect stem $(71.4 \%)$, semi-compact shaped ears $(68.1 \%)$, small size ears $(41.5 \%)$, no discontinuity of spikelet on finger $(92.0 \%)$, no lodging susceptibility at maturity $(61.8 \%)$, no spikelet shattering at maturity $(95.1 \%)$, enclosed grains covering by glumes $(71.5 \%)$, light brown colour grains $(34.9 \%)$, round shaped grains $(96.9 \%)$ and smooth grain surface $(95.0 \%)$. Important objective of any plant scientist is to identify an optimum number of plant traits which are sufficient to explain the maximum variability in the crop growth from sowing to harvest. Results of the study suggest a considerable morphological variability, which could exist among the studied accessions. This finding justifies the importance of germplasm characterization.

Copy Right, IJAR, 2017,. All rights reserved.

\section{Introduction:-}

Finger millet (Eleusinecoracana) [order Poales, family Poaceae, sub family Chloridoideae] ranks fourth in importance among milletsin the world after sorghum (Sorghum bicolor), pearlmillet (Pennisetumglaucum) and foxtail millet (Setariaitalica).This crop is grown in the arid and semiarid regions of the world. Historical records 
suggest that the origin of E. coracanaprobably happened about 5000 years ago at somewhere in the region that is currently known as Uganda. It has been cultivated in India since 3000 years ago (Sirinivasacharyet al., 2007).

Finger millet grain can be stored for years without storage pests, which makes it a perfect food grain commodity for famine prone areas (National Research Council 1996).

E. coracanahas a greater nutritional value. Both grain and hull of finger millet have considerable nutrient content. The grain contains carbohydrate, protein, fat, fibers, iron, calcium, minerals and essential amino acids such as leucine, tryptophan, phenylalanine and methionine.The hull contains protein, fiber, Calcium and phosphorus. Consequently, this can be considered as the major preventive agent against malnutrition. Content of each component can be changed according to the crop variety. However each and every variety has its own nutritive value.E. coracanais used as a traditional medicine for several diseases such as liver disease. Villagers make plait bracelets using leaves and clumps of this crop. Chemicals such as hydrocyanic acid are obtained from finger millet.Since finger millet grains are much harder it is less susceptible to diseases and pests. But Finger millet blast disease is one of threats for the farmers who cultivatefinger millet(Ulaganathan and Nirmalakumari, 2015).

There are several important attributes of finger millet including adaptability to adverse agro-ecological conditions with minimal inputs, tolerant to moisture stress, can be produced on marginal land where other crops cannot perform, and tolerant to acidic soil (Barbeau and Hilu, 1993).

The genetic diversity study of a crop species is essential in many aspects including effective utilization of germplasm in plant breeding programs, identification of appropriate sampling procedures for germplasm collection and conservation, obtaining some collections for efficient germplasm management and explicating the taxonomy, evolution and origin of crop species (Assefaet al., 2002; Bekele, 1985; Demissie and Bjonstrand, 1996). Therefore, important objective of any plant scientist is to identify an optimum number of plant traits which are sufficient to explain the maximum variability in the crop growth from sowing to harvest (Ulaganathan and Nirmalakumari, 2015). The present study was conducted to assess phenotypic diversity of randomly selected 42 finger millet germplasm accessions conserved at PGRC, Gannoruwa, Sri Lanka.

Major aim of this article is to reveal the few of qualitative morphological characteristics of the studied finger millet germplasm accessions. There are more studies that revealing the genetic diversity of finger millet germplasm accessions conserved in Sri Lanka using quantitative morphological markers and SSR markers (Dasanayaka (2016); Kaluthanthri and Dasanayaka, (2016); Wakistaet al., (2016)).

\section{Materials and Methods:-}

This study was performed on 42 germplasm accessions of finger millet conserved at the Plant Genetic Resource center (PGRC), Gannoruwa, Sri Lanka (Table 01). These 42 germplasm accessions comprised of 27 Sri Lankan accessions, 11 Indian accessions, 2 Zimbabian accessions and 2 recommended varieties of Sri Lanka.

Seeds of each accession were sown in small plastic pots filled with normal soil, and keep the spacing between the seeds. Pots were irrigated soon after sowing and placed in a plant house. Two weeks old seedlings were transplanted separately in the large plastic pots filled with mixture of soil, sand and compost (1:1:1) as each pot contained 4 plants. Data were recorded on twelve qualitative parameters. Qualitative traits taken into consideration were Pigmentation, Growth habit, Ear shape, Ear size, Finger branching, Discontinuity of spikelet, Lodging susceptibility, Spikelet shattering, Grains covering by glumes, Grain colour, Grain shape and Grain surface. Characters were scored following International Plant Genetic Resource Institute (IPGRI) descriptors developed for finger millet.

\section{Data Analysis:-}

Frequency distribution of ten polymorphic qualitative traits and its graphical representation were obtained using software IBM SPSS Statistics version 21 and Microsoft office excel 2007.

Table 01:-Details of the 42 finger millet germplasm accessions used for the study.

\begin{tabular}{|c|l|l|l|}
\hline Accession No. & Accession Name & Origin of Accession & Organization \\
\hline $\mathbf{1 2 2}$ & KobeyKurakkan & Moneragala & PGRC \\
\hline
\end{tabular}




\begin{tabular}{|c|c|c|c|}
\hline 190 & Gal Bora & Hambanthota & PGRC \\
\hline 192 & EDAL - KUR & Hambanthota & PGRC \\
\hline 258 & Kurakkan & Hambanthota & PGRC \\
\hline 418 & GAL Kurakkan & Kurunegala & PGRC \\
\hline 426 & EDAL Kurakkan & Kurunegala & PGRC \\
\hline 909 & INDAE/9 & India & Unknown \\
\hline 910 & HR 374 & India & Unknown \\
\hline 911 & SEL No - 4 & India & Unknown \\
\hline 923 & RAG15-6 & India & Unknown \\
\hline 925 & PR 202 & India & Unknown \\
\hline 926 & GPU 114 & India & Unknown \\
\hline 927 & PES 110 & India & Unknown \\
\hline 928 & GPU 5 & India & Unknown \\
\hline 959 & Kurakkan & NuwaraEliya & PGRC \\
\hline 960 & Kurakkan & NuwaraEliya & PGRC \\
\hline 962 & $\mathrm{JNR}-3 \mathrm{~B}-1008$ & India & RARS/AK \\
\hline 963 & $\mathrm{CO}-10$ & India & RARS/AK \\
\hline 964 & $\mathrm{KM}-1$ & India & RARS/AK \\
\hline 967 & Line 40 & Hambantota & PGRC \\
\hline 1201 & Kurakkan & Anuradhapura & PGRC \\
\hline 1233 & Kalu Gal Kurakkan & Matale & PGRC \\
\hline 1304 & KiriMoraKurakkan & Rathnapura & PGRC \\
\hline 1331 & BalaKurakkan & Rathnapura & PGRC \\
\hline 1815 & BalaKurakkan & Kandy & PGRC \\
\hline 1828 & Kalu Gal Kurakkan & Kandy & PGRC \\
\hline 3011 & Kurakkan & Hambanthota & PGRC \\
\hline 3021 & Maha Mora Kurakkan & Hambantota & PGRC \\
\hline 4989 & Kurakkan & Puttalam & PGRC \\
\hline 6580 & Kurakkan & Moneragala & PGRC \\
\hline 6586 & Kurakkan & Matale & PGRC \\
\hline 7089 & Kurakkan & Kurunegala & PGRC \\
\hline 7109 & SDFM 1143 & Zimbabwe & ICRISAT \\
\hline 7123 & SDFM 2564 & Zimbabwe & ICRISAT \\
\hline 7769 & Kurahan & Polonnaruwa & PGRC \\
\hline 7777 & Kurakkan & Badulla & PGRC \\
\hline 8389 & HaramusKurakkan & Anuradhapra & PGRC \\
\hline 8470 & Makala Kurakkan & Moneragala & PGRC \\
\hline 8796 & Kurakkan & Kegalle & PGRC \\
\hline 9083 & KahaKurakkan & NuwaraEliya & PGRC \\
\hline 9294 & Ravi & Recomended variety & PGRC \\
\hline 10326 & Ravana & Recomended variety & PGRC \\
\hline
\end{tabular}

\section{Results:-}

Out of 12 recorded qualitative morphological traits, only two traits namely pigmentation and Finger branching did not show any range of variability across the studied 42 germplasm accessions. In other words, none of individual 
plant showed any kind of pigmentation or finger branching. The frequency distribution of ten polymorphic qualitative traits is given in Table 02 and its graphical representation is shown in Figure 01.

In this study, three morphological states of growth habit (erect, prostrate and decumbent) were observed. Results showed that majority of plants (71.4\%) were erect, 120 plants (24.0\%) were Prostrate and the remaining 23 plants (4.6\%) were decumbent.

Four morphological states of ear shape were observed. Majority of plants was found to possess (68.0\%) semicompact shape whereas 95 plants (19.0\%), 52 plants (10.4\%) and 13 plants (2.6\%) were found to possess Compact, Open and Fist like shapes respectively.

In case of ear size, small size ears were found in 208 plants (41.6\%), intermediate size ears were found in 156 plants $(31.2 \%)$ and only 136 plants $(27.2 \%)$ were found to found to possess large size ears.

Among 500 individual plants, only 40 plants $(8.0 \%)$ were found to possess discontinuity of spikelet on finger of their ears.

Based on lodging susceptibility at maturity, it was observed that among studied plants, 309 plants $(61.8 \%)$ were not lodged at all while rest of plants was lodged. In here, 93 plants (18.6\%) showed low lodging, 49 plants (9.8\%), showed intermediate lodging and rest of 49 plants (9.8\%) showed high lodging.

Regarding Spikelet shattering at maturity, majority of plants (95.0\%) were not found to possess ears which shattered their spikelet at maturity.

Three types of glumes were observed in this study. Most of grains (71.6\%) were completely covered by glumes (Enclosed) and $17.4 \%$ of grains was partially covered by glumes (Intermediate). Remaining $11.0 \%$ of grains was not covered by glumes.

Four types of grain colour were observed in finger millet those used in this study. Among the studied plants, 175 plants (35.0\%) had light brown colour grains, 150 plants (30.0\%) had Dark brown grains, 135 plants (27.0\%) had Copper brown colour grains and remaining 40 plants (8.0\%) had White colour grains.

Only two grain shapes were observed in this study. Majority of plants (97.0\%) had round shaped grains whereas remaining plants $(3.0 \%)$ had reni form shaped grains.

In the case of grain surface, majority of plants $(95.0 \%)$ had smooth grains while remaining plants had grains with wrinkled surface. 


\section{Growth habit}

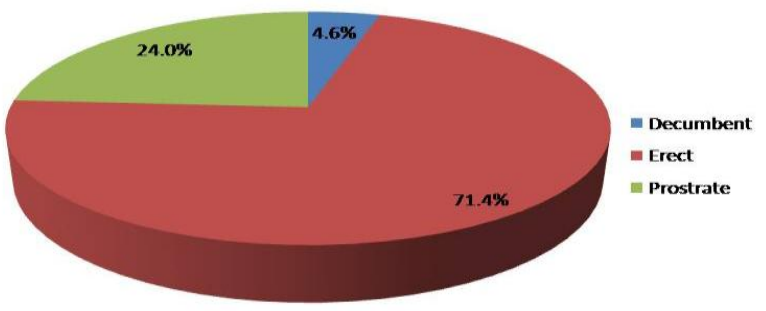

3. Ear size

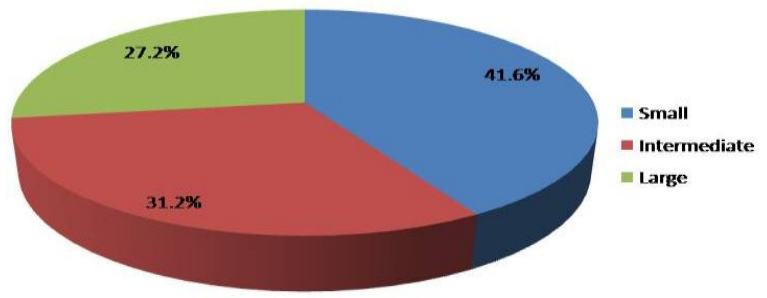

5. Lodging susceptibility at maturity

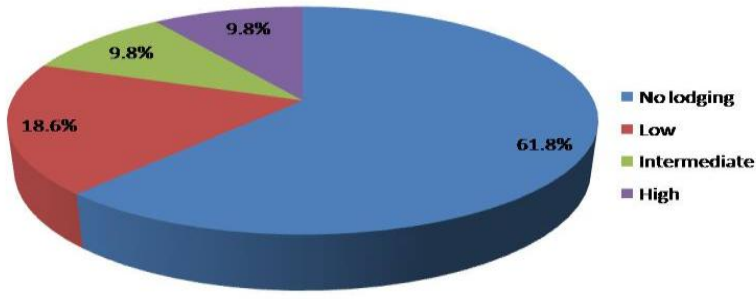

7. Grain covering by glumes

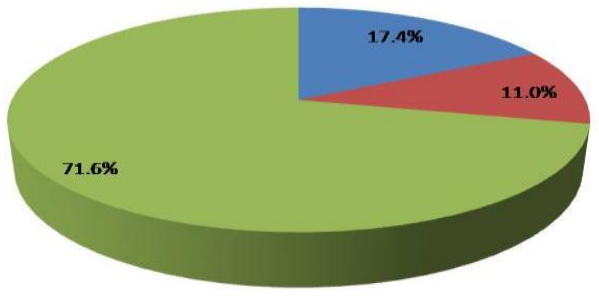

9. Grain shape

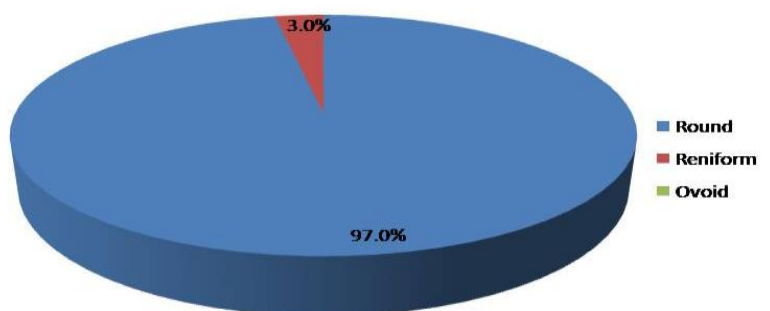

2. Ear shape

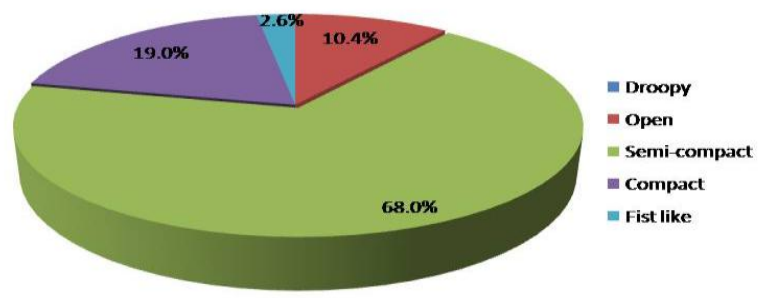

4. Discontinuity of spikelets on finger

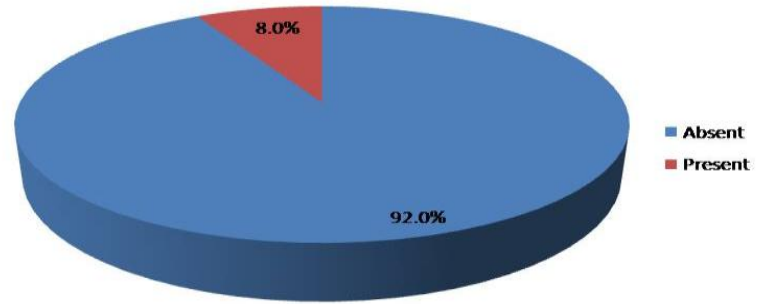

6. Spikelet shattering at maturity

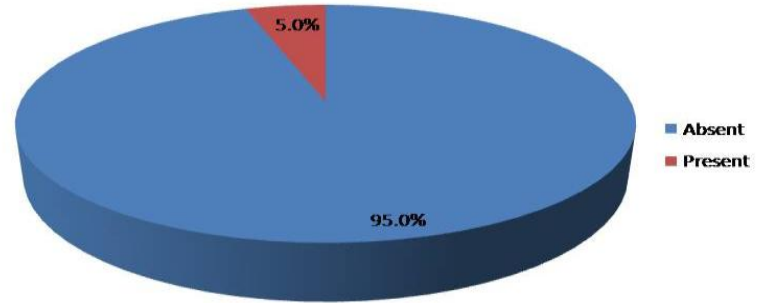

8. Grain colour

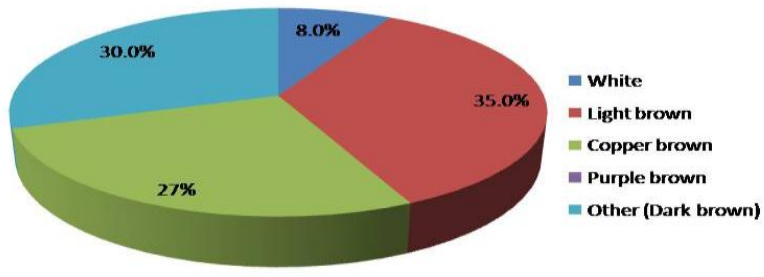

10. Grain surface

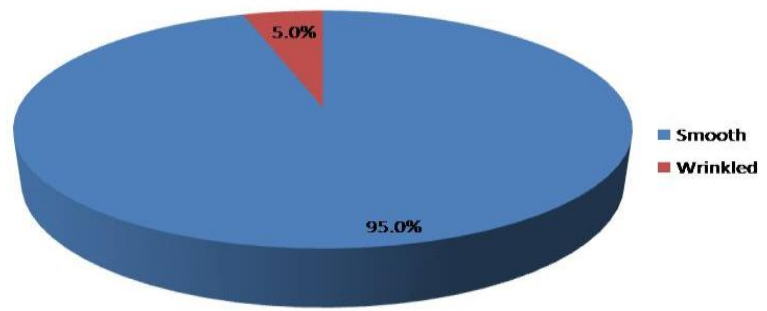

Figure 1:- Graphical representation for frequency distribution of ten polymorphic qualitative traits of finger millet 
Table 2:-Frequency distribution of ten polymorphic qualitative traits in finger millet germplasm accessions

\begin{tabular}{|c|c|c|c|}
\hline Morphological character & Character type & Frequency & Valid Percent (\%) \\
\hline \multirow[t]{3}{*}{ 1. Growth habit } & Decumbent & 23 & 4.6 \\
\hline & Erect & 357 & 71.4 \\
\hline & Prostrate & 120 & 24.0 \\
\hline \multirow[t]{5}{*}{ 2. Ear shape } & Droopy & 0 & 0 \\
\hline & Open & 52 & 10.4 \\
\hline & Semi-compact & 340 & 68.0 \\
\hline & Compact & 95 & 19.0 \\
\hline & Fist like & 13 & 2.6 \\
\hline \multirow[t]{3}{*}{ 3. Ear size } & Small & 208 & 41.6 \\
\hline & Intermediate & 156 & 31.2 \\
\hline & Large & 136 & 27.2 \\
\hline \multirow[t]{2}{*}{ 4. Discontinuity of spikelet on finger } & Absent & 460 & 92.0 \\
\hline & Present & 40 & 8.0 \\
\hline \multirow[t]{4}{*}{ 5. Lodging susceptibility at maturity } & No lodging & 309 & 61.8 \\
\hline & Low & 93 & 18.6 \\
\hline & Intermediate & 49 & 9.8 \\
\hline & High & 49 & 9.8 \\
\hline \multirow{2}{*}{ 6. Spikelet shattering at maturity } & Absent & 475 & 95.0 \\
\hline & Present & 25 & 5.0 \\
\hline \multirow[t]{3}{*}{ 7. Grain covering by glumes } & Exposed & 87 & 17.4 \\
\hline & Intermediate & 55 & 11.0 \\
\hline & Enclosed & 358 & 71.6 \\
\hline \multirow[t]{5}{*}{ 8. Grain colour } & White & 40 & 8.0 \\
\hline & Light brown & 175 & 35.0 \\
\hline & Copper brown & 135 & 27 \\
\hline & Purple brown & 0 & 0.0 \\
\hline & Other (Dark brown) & 150 & 30.0 \\
\hline \multirow[t]{3}{*}{ 9. Grain shape } & Round & 485 & 97.0 \\
\hline & Reniform & 15 & 3.0 \\
\hline & Ovoid & 0 & 0.0 \\
\hline \multirow[t]{2}{*}{ 10. Grain surface } & Smooth & 475 & 95.0 \\
\hline & Wrinkled & 25 & 5.0 \\
\hline
\end{tabular}

\section{Discussion:-}

In this study, three morphological states of growth habit (erect, prostrate and decumbent), four morphological states of ear shape (open, semi compact, compact and fist like), three morphological states of ear size (small, intermediate and large), four morphological states for lodging susceptibility (no lodging, low lodging, intermediate lodging and high lodging), three morphological states of grains covered by glumes (exposed, intermediate and enclosed), four morphological states of grain color (white, light brown, copper brown and dark brown), two morphological states of grain shape (round and reniform) and two morphological states for grain surface (smooth and wrinkled)were observed in studied finger millet germplasm accessions. Furthermore, discontinuity of spikelet on finger and spikelet shattering at maturity were not observed in majority of germplasm accessions used in this study.

The majority of individual plants was found to possess erect stem (71.4\%), semi-compact shaped ears (68.0\%), small size ears (41.6\%), no discontinuity of spikelet on finger (92.0\%), no lodging susceptibility at maturity $(61.8 \%)$, no spikelet shattering at maturity (95.0\%), enclosed grains covering by glumes (71.6\%), light brown colour grains $(35.0 \%)$, round shaped grains $(97.0 \%)$ and smooth grain surface $(95.0 \%)$. 
According to the plant colour, finger millet germplasm accessions can be classified into two groups as green colour plants and pigmented plants. There were no pigmented plants with respect to any of studied accessions. Therefore, the trait, pigmentation can be considered as a monomorphic character in this study. Similarly, the character, finger branching can be considered as a monomorphic character reason being not observed in any of studied accessions.

Decumbent, erect and prostrate are the three types of growth habit that can be found in finger millet. In this study, erect type was predominant with frequency of $71.4 \%$ followed by prostrate type with frequency of $24.0 \%$ where as prostrate type was found in only few individuals from several accessions. However as Bezaweletawet al.(2007) reported the variation in growth habit showed that the decumbent type was more predominant in all regions followed by prostrate type with overall frequency of $25 \%$ whereas erect type was found to concentrate in one region with a frequency of 34\%. Type of growth habit of a plant involves in its capacity to suppress weeds at early growth stage and its capacity to withstand against the moisture stress. Apparently, if the architecture of a plant can reduce the evapo-transpiration by covering the soil at early stage such architecture could enable the plant to perform better. According to Bezaweletawet al.(2007), prostrate type and decumbent typemight be highly preferred by most farmers in different regions which could be due to their capacity to suppress weeds at early growth stage and ability to withstand moisture stress.

According to De Wet et al. (1984), inflorescence morphology was associated with grain yield and is used by the farmers to distinguish complexes of cultivars. In this study semi-compact type of ear shape was predominant with frequency of $68.0 \%$ whereas droopy ear shape was not found in any plant.

In the case of ear size, majority of plants (41.6\%) composed of small size ears whereas $31.2 \%$ and $27.2 \%$ of plants composed of intermediate and large size ears respectively.

In this study $92.0 \%$ of plants did not show discontinuity of spikelet on finger.

Lodging can be defined as the permanent displacement of a plant from its vertical position. Lodging of finger millet plants was recorded by looking at the angle of displacement of the stem from the vertical position where $0^{\circ}$ is no displacement. In this study, no lodging was predominant with frequency of $61.8 \%$ followed by low lodging with frequency of $18.6 \%$ whereas intermediate and high lodging plants were found with equal frequency of $9.8 \%$. In finger millet, grain yield can be reduced mainly due to moisture scarcity and lodging susceptibility of the plants. And also lodging can be resulted in shriveled and poor quality seed that sprouts on the panicle before harvest. Plant height and Culm thickness have major effect on the lodging susceptibility of a plant.

Spikelet shattering at maturity was absent in $95.0 \%$ of plants in this study. One of the key changes often regarded as the characteristic of domesticated grain crops was a shift from natural seed dispersal through shattering mechanisms to obligate dispersal by people (Zohary, 1969; Harlan et al., 1973; Hillman and Davies, 1990, 1999). Shattering occurs by the abscission at the abscission scars, such as the rachilla to spikelet base attachment. But as a result of the loss of abscission at the abscission scars, a plant retains seeds instead of shedding them when they are mature and they are then usually separated by the addition of human labour (threshing and winnowing). This increases the efficiency of harvest and thus yields.

In this study, Majority of plants (71.6\%) composed of enclosed grains covering by glumes. In other words majority of grains had tightly bound seed coats with their edible part. However this character state is kind of a challenge to threshing and milling processes (Tsehay and Kebebew, 2002).

Four different grain colours including Light brown (35.0\%), Dark brown (30.0\%), Copper brown (27.0\%) and White $(8.0 \%)$ were observed in this study. However, purple brown coloured grains were not found in this study. Grain colour can be considered as one of the most important traits reason being its involvement in the determination of the quality of the cultivars. As described by Tsehaye and Kebebw (2002), grain colourhas an economic value because it is used in variety identification and commercial classification of different varieties of crops. White and reddish coloured grains have considerably high economic value compared to that of dark coloured grains. But farmers prefer to grow dark coloured grains because of its high yield and hardiness with respect to climatic hazards such as poor soil fertility. (Kefyalew and Ensermu, 1989). An apparent association between grain colour and human consumption of finger millet can be observed with in Ethiopia as reported by Zemede (1988). 
In this study, round shaped grains and smooth surface grains were predominant with frequencies of $97.0 \%$ and 95.0\% respectively. As reported by Bezaweletawet al.(2007), though their adaptive significance is not known, grains with round shape and smooth surface are preferred by consumers in Ethiopia. In the case of finger millet consumption, threshing and milling processes should be performed beforehand. In here, especially in milling, round shaped and smooth surfaced grains might be more advantageous.

\section{Conclusion:-}

The genetic diversity study of a crop species is essential in many aspects including effective utilization of germplasm in plant breeding programs, identification of appropriate sampling procedures for germplasm collection and conservation, obtaining some collections for efficient germplasm management and explicating the taxonomy, evolution and origin of crop species.In this process, qualitative characters are useful in precise characterization of germplasm. The study of 12 qualitative characters revealed that the considerable morphological variation exist among the studied accessions especially for characters such as growth habit, ear shape, ear size, lodging sisceptibility, grain covering by glume and grain colour. Findings of this study provide a clue for germplasm collection and conservations.

\section{References:-}

1. Assefa, K., Tefera, H., and Arnulf, M. (2002).Variation and interrelationship of quantitative trait in tef (Eragrostistef(Zucc.) Trotter) germplasm from western and south western Ethiopia. Hereditas 136:pp.116-125.

2. Barbeau, W.E., Hilu, K. (1993). Protein, calcium, iron and amino acid content of selected wild and domesticated cultivars of Wnger millet. Plant Foods Hum. Nutr. 43:pp.97-104.

3. Bekele, E. (1985). The biology of cereal landrace populations. Problem of gene conservation, plant breeding schemes and sample size requirement. Hereditas 103:pp.119-134.

4. Bezaweletaw, K., Sripichitt, P., Wongyai, W. and Hongtrakul, V.( 2007). Phenotypic Diversity of Ethiopian Finger Millet [Eleusinecoracana (L.) Gaertn] in Relation to Geographical Regions as an Aid to Germplasm Collection and Conservation Strategy. Kasetsart J. (Nat. Sci.) 41(1):pp.7-16

5. Dasanayaka P.N (2016). Characterization of some ex-situ conserved finger millet (Eleusinecoracana (L.)) germplasm accessions in Sri Lanka. International Journal of Multidisciplinary Studies. 3(2). Pp.141-150.

6. De Wet, J.M.J., Prasada Rao, K.E., Brink, D.G. and Mengesha, M.H. (1984). Systemic evolution of Eleusinecoracana (Graminea). Amer. J. Bot. 7: pp.550-557.

7. Demissie, A., and Bjonstrand, A. (1996). Phenotypic diversity of Ethiopian barley in relation to geographic regions, altitudinal range and agro ecological zones: as an aid to germplasm collection and conservation strategy. Hereditas 124:pp.17-29.

8. Harlan, J.R., De Wet, J.M.J. and Price, E.G. (1973) Comparative evolution of cereals. Evolution 27, pp. 311-325.

9. Hillman, G.C. and Davies, M.S. (1990) Domestication rates in wild wheats and barley under primitive cultivation. Biological Journal of the Linnean Society 39, pp.39-78.

10. Hillman, G.C. and Davies, M.S. (1999) Domestication rate in wild wheats and barley under primitive cultivation: preliminary results and archaeological implications of field measurements of selection coefficient. In: Prehistory of Agriculture. New Experimental and Ethnographic Approaches (ed. P.C. Anderson), Monograph 40. Institute of Archaeology, University of California, Los Angeles, pp 70-102.

11. Kaluthanthri, D.V.S. and Dasanayaka, P.N. (2016). Assessment of Genetic Diversity of Some Finger Millet (Eleusinecoracana (L.) Gaertn. Accessions Using Morphological Markers. Journal of Tropical Forestry and Environment. 6(02). Pp. 25-35.

12. Kefyalew, A. and Ensermu, R. (1989). Initial Results of Informal Survey Bahir Dar Mixed Farming Zone. No. 5. Institute of Agricultural Research. Addis Ababa.pp 31

13. National Research Council. (1996). Lost crops of Africa. Vol.1.Grains. Washington, DC, USA: National Academy Press. pp.383

14. Plaza-Wuthrich, S., Blosch, R., Rindisbacher,A., Cannarozzi, G. and Tadele, Z. (2016). Gibberellin Deficiency Confers Both Lodging and Drought Tolerance in Small Cereals. Front Plant Sci.7: pp.643. https://www.ncbi.nlm.nih.gov/pmc/articles/PMC4865506/ Accessed 12 January, 2017.

15. Singh, K.B. and Saxena, M.C. (1999). Chickpeas. The Tropical Agriculturalist. MacMilan Education Ltd., London. Pp.134.

16. Srinivasachary.,Dida, M.M., Gale, M.D. andDevos, K.M. (2007). Comparative analyses reveal high levels of conserved colinearity between the finger millet and rice genomes. Theoretical and Applied Genetics, 115(4):489-499.

17. Tsehaye, T. and Kebebew, F. (2002). Morphological diversity and geographic distribution of adaptive traits in finger millet [Eleusinecoracana (L.) Gaertn. (Poaceae)] populations from Ethiopia. Ethiopian J. Biol. Sci. 1: pp.37- 62. 
18. Ulaganathan, V. and Nirmalakumari, A. (2015) Finger millet germplasm characterization and evaluation using principal component analysis. SABRAO Journal of Breeding and Genetics. 47 (2). pp.79-88.

19. Wakista PW, Dasanayaka PN, Illeperuma RJ, Perera SACN (2016). Assessment of genetic diversity of a representative sample of finger millet (Elecusinecoracana (L.) Gaertn) collected from four different districts of Sri Lanka using SSR markers. Sri Lankan Journal of Biology. 2(1). Pp.1-8.

20. Zemede, A. (1988). Variation in the morphology of the spike within Ethiopian barley, Hordeumvulgare L. (Poaceae). Acta Agric. Scand 38: pp.277-288.

21. Zohary, D. (1969) The progenitors of wheat and barley in relation to domestication and agriculture dispersal in the Old World. In: The Domestication and Exploitation of Animals and Plants (eds P.J. Ucko and G.W. Dimbleby). Duckworth, London, pp 47-66. 